\title{
Severe Hypertension and Hypokalemia as First Clinical Manifestations in Ectopic Cushing's Syndrome
}

apresentação de caso

EVA FERNÁNDEZ-RODRÍGUEZ

ROcío VILLAR-TAIBO

IrIA PINAL-OSORIO

José Manuel Cabezas-Agrícola

URBANO ANIDO-HERRANZ

ALMA PrIeto

Felipe F CASANUEVA

DaVid Araujo-Vilar

Endocrinology and Nutrition Service (EFR, RVT, IPO, JMCA, AP FFC, DAV); Medical Oncology Service (UAH), University Clinical Hospital of Santiago de

Compostela, Spain; U.E.T.e M. Department of Medicine,

Faculty of Medicine, University of Santiago de Compostela, Spain (DAV).

Recebido em $x x / x / 2008$

Aceito em $x / x / 2008$

\section{ABSTRACT}

Ectopic ACTH production occurs in about $10 \%$ of all cases of Cushing's syndrome, and about $25 \%$ of cases of ACTH-dependent Cushing's syndrome. Diverse tumor types are able to produce ACTH ectopically, including small cell lung carcinoma. Ectopic ACTH secretion by malignant neoplasm has been reported to have earlier and more aggressive metabolic effects. We report a 59-year-old male patient with severe hypertension, metabolic alkalosis and hypokalemia as the first clinical manifestations of an ACTH-secreting small cell lung carcinoma, although the typical phenotypic features of Cushing's syndrome were not present. Ectopic Cushing's syndrome should always be ruled out in patients with severe hypertension and hypokalemia. (Arq Bras Endocrinol Metab 2008; 52/6:1066-1070)

Key words: Cushing's syndrome; Ectopic ACTH production; Small cell lung cancer; Hypokalemia

\section{RESUMO}

Hipertensão Grave e Hipocalemia Como Primeiras Manifestações Clínicas em Casos de Síndrome de Cushing Ectópica.

A produção de ACTH ectópico ocorre em aproximadamente $10 \%$ dos casos de síndrome de Cushing, e em aproximadamente $25 \%$ dos casos de síndrome de Cushing dependentes de ACTH. Diversos tipos de tumores são capazes de produzir ACTH ectopicamente, incluindo carcinoma pulmonar de células pequenas. Relatórios indicam que a secreção de ACTH ectópico por neoplasma maligno causa efeitos metabólicos prematuros e mais agressivos. Apresentamos um paciente, 59 anos, com hipertensão grave, alcalose metabólica e hipocalemia, tendo estas como as primeiras manifestações clínicas de um carcinoma pulmonar de células pequenas com secreção de ACTH, embora as características fenótipas típicas da síndrome de Cushing não estavam presentes. A síndrome de Cushing ectópica deveria ser excluída sempre em pacientes com hipertensão grave e hipocalemia. (Arq Bras Endocrinol Metab 2008; 52/6:1066-1070)

Descritores: Síndrome de Cushing; Produção de ACTH ectópica; Câncer pulmonar de células pequenas; Hipocalemia

\section{INTRODUCTION}

- CTOPIC SECRETION OF ACTH (by a nonpituitary tumor) accounts for about

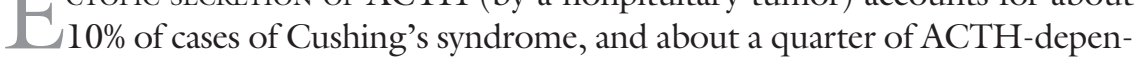
dent cases (1). Many types of tumor can secrete ACTH, including carcinoid tumors, small cell lung cancer, and medullary carcinoma of thyroid. Clinical course is influenced by the type of tumor: ectopic ACTH secretion by malignant neoplasms typically leads to early-appearing and rapidly augmenting metabolic 
alterations. In contrast, in cases of ectopic ACTH secretion by less aggressive tumors, diagnosis may be delayed and clinical characteristics will often be similar to those of pituitary Cushing's syndrome. Hypokalemia is a common finding in many endocrinology disorders which may be always excluded as hypermineralocortisolism or Cushing syndrome, including ectopic ACTH secretion. Here we report a patient with severe arterial hypertension, metabolic alkalosis and hypokalemia as presentations of ACTH secretion by a small cell lung carcinoma.

\section{CASE REPORT}

A 59-year-old man was admitted to the Endocrinology Department of our hospital in view of severe arterial hypertension, metabolic alkalosis and hypokalemia. His history included arterial hypertension first noted more than 20 years previously to that and it was required three drugs for control (a beta-blocker, a calcium antagonist and a thiazidic diuretic). He smoked 60 cigarettes per day, and reported moderate alcohol consumption. He had already presented at the Emergency Department of his reference hospital in view of general malaise commencing 24 hours previously, with paresthesias in both arms and legs, and in the peribuccal region. $\mathrm{He}$ also showed severe and intractable arterial hypertension, and analysis indicated metabolic alkalosis and severe hypokalemia ( $\mathrm{pH} 7.57, \mathrm{HCO}_{3}^{-} 40 \mathrm{mmol} / \mathrm{L}, \mathrm{pCO}_{2}$ $\left.55,9 \mathrm{~mm} \mathrm{Hg}, \mathrm{K}^{+} 1.6 \mathrm{mmol} / \mathrm{L}\right)$ with normal calcemia. He was therefore referred to our Department.

On arrival, arterial tension was high $(202 / 102 \mathrm{~mm}$ $\mathrm{Hg}$ ) despite the antihypertensive medication. $\mathrm{He}$ also presented pitting edema on both legs extending to the upper thighs, and a holosystolic murmur. Other exam findings were normal. Chest radiography revealed a mass in the right hilum suggestive of neoplasm.

Admission biochemistry indicated mild hyponatremia and severe hypokalemia (134 and $1.6 \mathrm{mmol} / \mathrm{L}$, respectively), together with metabolic alkalosis. Calcemia, phosphatemia and magnesemia were all within normal limits.

In view of these findings we initiated a protocol for detection of endocrine hypertension, including tests for Cushing's syndrome, primary hyperaldosteronism and pheochromocytoma. Basal pituitary hormone tests indicated raised levels of plasma cortisol (normal range: $5-25 \mu \mathrm{g} / \mathrm{dl}$ ) and ACTH (normal range: $0-46 \mathrm{pg} / \mathrm{ml}$ ) (Table 1), without changes in other pituitary hormones.
The method used to determinate ACTH, cortisol and FUC (normal range: $40-258 \mu \mathrm{g} / 24 \mathrm{~h}$ ) was the quimioluminiscence (Siemens). Inter and intraassay coefficients of variation were $10 \%$ and $<9.5 \%$, respectively for $\mathrm{ACTH}$ and $<9.4 \%$ and $7.4 \%$ respectively for cortisol and FUC.

Urinary catecholamines, metanephrines and normetanephrines were normal, and tests for hyperaldosteronism were negative. 24-hour urinary cortisol excretion was very high $(>5000 \mu \mathrm{g})$. An overnight dexamethasone suppression test (single dose of $8 \mathrm{mg}$ of dexamethasone) resulted a morning cortisol level of $42 \mu \mathrm{g} /$ $\mathrm{dL}(6.6 \%$ suppression with respect to the basal level of $45 \mu \mathrm{g} / \mathrm{dL}$ ) (Table $\mathrm{l})$.

These results, together with the clinical and radiological findings, supported the diagnostic hypothesis of ectopic ACTH-dependent Cushing's syndrome.

On the second day of hospitalization the patient presented severe delusions of persecution and extreme agitation, requiring neuroleptic medication for control. The hypokalemia persisted, requiring high intravenous $\mathrm{K}$ supply (up to $280 \mathrm{mEq}$ per day; [Figure 1]), and the arterial hypertension could not be effectively controlled despite administration of enalapril/amlodipine/ spironolactone (once primary hyperaldosteronism was excluded).

No further complications were noted until the day 15 , when the patient presented abdominal pain and vomiting, leading to a diagnosis of acute pancreatitis with torpid course requiring antibiotic therapy. When remission commenced, the patient suffered a hypertensive crisis with severe respiratory failure due to acute pulmonary edema. Intensive treatment with loop diuretics and oxygen therapy achieved full recovery.

Table 1. Time-course of biochemical determinations.

\begin{tabular}{cccc}
\hline DAY & $\begin{array}{c}\text { FUC }(\mu \mathrm{g} / 24 \mathrm{~h}) \\
\text { NR: } \mathbf{4 0 - 2 5 8}\end{array}$ & $\begin{array}{c}\text { Cortisol }(\mu \mathrm{g} / \mathrm{dl}) \\
(\mathbf{0 8 : 0 0} \mathrm{am}) \\
\text { NR: } \mathbf{5 - 2 5}\end{array}$ & $\begin{array}{c}\text { ACTH }(\mathrm{pg} / \mathrm{ml}) \\
\text { NR: } \mathbf{0 - 4 6}\end{array}$ \\
\hline 7 & & 42 & \\
11 & 5235 & 41 & 90 \\
19 & & 45 & \\
\hline 19 & 5203 & & 114 \\
\hline 21 & & 42 & \\
\hline 25 & 3392 & & \\
\hline 31 & 1026 & & \\
\hline 36 & 445 & & \\
\hline
\end{tabular}

FUC = free urinary cortisol; NR = normal range 


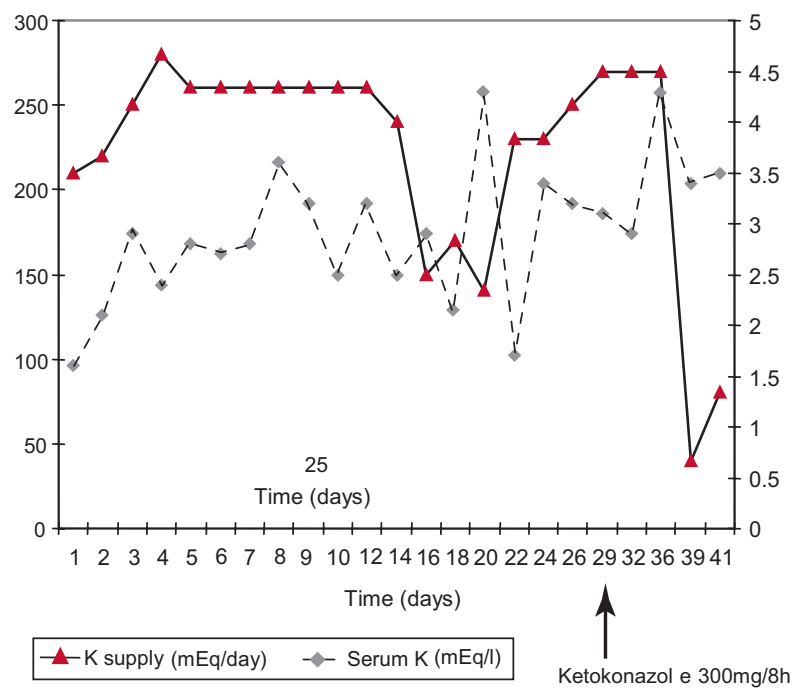

Figure 1. Relationship between $\mathrm{K}^{+}$supply and serum $\mathrm{K}^{+}$level over the period of study.

Chest CT scans showed a $3-\mathrm{cm}$ hilar mass with infiltration of the left lobe bronchus and moderate left pleural effusion. Bronchoscopic biopsies indicated small cell lung carcinoma, with negative immunostaining for ACTH. Abdominal CT revealed two bilateral suprarenal masses with maximum $6 \mathrm{~cm}$ diameter and heterogeneous enhancement, suggestive of neoplasm.

While waiting for the patient's basal situation to improve before starting chemotherapy, ketoconazole was started at $900 \mathrm{mg} /$ day, leading to a clear improvement in the psychotic symptoms, a gradual reduction in 24-h urinary cortisol excretion, and adequate control of the hypertension and alkalosis. $\mathrm{K}^{+}$levels were maintained within the normal range with daily administration of $50-70 \mathrm{mEq}$ (Figure 2).

Palliative chemotherapy with carboplatin and etoposide was subsequently commenced. The patient was discharged 9 days later, but readmitted after 48 h because of febrile neutropenia probably due to respiratory infection. Despite a good initial response to treatment with ceftazidime-amikacin, the patient worsened and developed septic shock, dying a few days later.

\section{DISCUSSION}

Ectopic Cushing's syndrome accounts for scarcely 10\% of cases of hypercortisolism. About one half of cases are

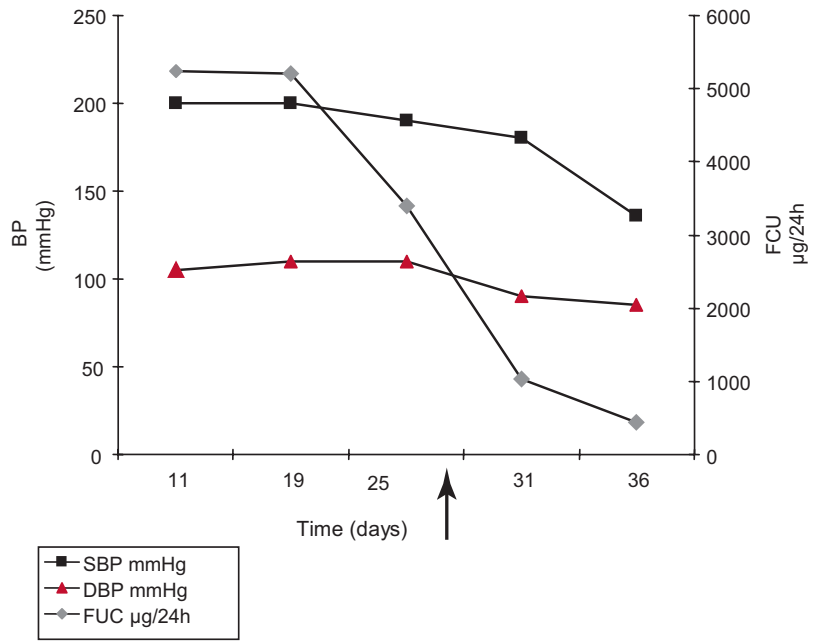

Figure 2. Influence of ketokonazole on high blood pressure and its relationship with cortisoluria. SBP: Systolic Blood Pressure, DBP: Diastolic Blood Pressure, FUC: Free urinary cortisol.

associated with a small cell lung cancer. The prevalence of Cushing's syndrome among small cell lung carcinoma patients is about $5 \%(2)$.

The case reported here presented as an intractable hypertensive crisis associated with hypokalemia and metabolic alkalosis. High urinary cortisol excretion and the hilar mass observed in chest radiographs strongly suggested that the clinical symptoms were due to a malignant ACTH-secreting neoplasm. Although the association of arterial hypertension and hypokalemia is often attributable to primary hyperaldosteronism, other causes should not be ruled out, in view of the mineralocorticoid action of high cortisol concentrations. Under normal conditions the mineralocorticoid effect of cortisol is insignificant, due to local conversion to cortisone by the action of 11 beta-hydroxysteroid dehydrogenase. When plasma concentrations of cortisol are very high, the action of this enzyme is insufficient, and mineralocorticoid effects appear.

In our patient, the initial response to antihypertensive treatment was weak, in part because the initial need to test for endocrine hypertension restricted the therapeutic options available. The severity of the hypertension, leading to acute pulmonary edema, was probably due to the association of essential hypertension and severe endogenous hypercortisolism. Cushing's syndrome can cause high blood pressure via diverse mechanisms, to which we should add the mineralocorticoid effect of our 
patient's severe hypercortisolemia. In fact, high blood pressure was well-controlled once hypercortisolemia was reduced by ketokonazole treatment.

Noteworthy were the pronounced and persistent psychotic signs seen in our patient, associated with the severe hypercortisolism, and improving after its control. The presence of neuropsychiatric symptoms in Cushing's syndrome is widely documented (3), with a prevalence of over $40 \%$ in some series (4). The most frequent disorder is depression, with psychosis less frequently, probably because it is more difficult to be detected, due to the tendency of psychotic patients to hide or attenuate symptoms, and also to a lack of awareness of the disorder $(4,5)$.

The test of choice for differential diagnosis of pituitary and ectopic ACTH-dependent Cushing's syndrome is blood sampling from the inferior petrosal sinuses after administration of CRH: a pituitary-peripheral ratio of more than 2 indicates pituitary rather than ectopic ACTH secretion (sensitivity 97\%, specificity $100 \%$ ) (6). Desmopressin can also be an option for ACTH stimulation during this procedure, improving the accuracy of the differential diagnosis of ACTH-dependent Cushing's syndrome by amplifying the pituitary-peripheral ratio (7). Moreover, recent published data has suggested that the application of a combined stimulation with CRH plus desmopressin is associated with a high sensitivity without losing specificity (8).

High-dose dexametasone suppression tests, though reinforcing the diagnosis, have lower sensitivity $(81 \%)$ and specificity $(67 \%)(9)$. In the present patient, the rapid clinical course meant that it was not possible to perform pituitary MR imaging or the tests generally considered as gold standards for ectopic ACTH-independent Cushing's syndrome: nevertheless, we can establish this diagnosis with high probability, since this was a patient with ACTHdependent Cushing's syndrome, without characteristic phenotype, with severe metabolic alkalosis and hypokalemia, with a tumor type that can cause Cushing's syndrome, with raised ACTH, and with a positive result in the high-dose dexamethasone suppression test.

The fact that ACTH immunohistochemistry results were negative is not surprising, since ACTH-immunonegative cases of ectopic Cushing's syndrome have been described previously (10). However, we cannot rule out the possibility that the lung carcinoma was producing $\mathrm{CRH}$, not ACTH $(11,12)$.

We considered the adrenal masses to have been metastases, despite the lack of histological confirmation, in view of CT scan characteristics indicating malignancy, and given that metastatic lesions of this type occur in about $20 \%$ of cases of lung cancer. Necropsy to confirm this suspicion was not possible.

It has been reported that small cell lung carcinoma patients with ectopic Cushing's syndrome show poorer course than patients without this syndrome, and the course seen in the present case is in line with this view $(1,3)$. In addition, these patients develop more frequent complications, such as infections, gastrointestinal bleeding and gastric ulcer perforation.

Ketoconazole is used for treatment of Cushing's syndrome because it inhibits adrenal glucocorticoid synthesis. However, there have been few published studies on its utility in ectopic Cushing's syndrome, and the results have been controversial. Winquist et al. (13) conclude that ketoconazole does not prolong survival but promotes a palliative hormonal response in $2 / 3$ of patients. In our patient, ketoconazole at $900 \mathrm{mg} /$ day resolved the hypokalemia, reduced the hypercortisolism and improved the psychotic symptoms.

Carboplatin/etoposide chemotherapy is currently considered the standard treatment for small cell lung carcinoma (14).

Bilateral adrenalectomy may play a role in the management of these patients, as it provides long-term benefit from the metabolic and catabolic manifestations of glucocorticoid excess (15)

Moreover, bilateral laparoscopic adrenalectomy has been suggested as the procedure of choice in the management of patients who have persistent hypercortisolism despite tumour directed treatments (16).

In conclusion, ectopic Cushing's syndrome is an uncommon cause of hypercortisolism, but should be ruled out in patients with hypokalemic metabolic alkalosis and arterial hypertension, despite the absence of a characteristic phenotype, and especially in the context of lung neoplasm.

\section{REFERENCES}

1. Noorlander I, Elte JW, Manintveld OC, Tournoy KG, Praet MM van Meerbeeck JP et al. A case of recurrent non-small-cel lung carcinoma and paraneoplastic Cushing's syndrome. Lung Cancer. 2006;51:251-5.

2. Shepherd FA, Laskey J, Evans WK, Goss PE, Johansen E, Khamsi F. Cushing's syndrome associated with ectopic corticotropin production and small-cell lung cancer. J Clin Oncol 1992;10:21-7. 
3. Yoh K, Kubota K, Nomura M, Niho S, Goto K, Ohmatsu H et al. Cushing's syndrome associated with adenocarcinoma of the lung. Intern Med. 2003;42:831-3.

4. Chu JW, Matthias DF, Belanoff J, Schatzberg A, Hoffman AR, Feldman D. Successful long-term treatment of refractory Cushing's disease with high-dose mifepristone (RU 486). J Clin Endocrinol Metab. 2001;86:3568-73.

5. Dorn LD, Burgess ES, Friedman TC, Dubbert B, Gold PW, Chrousos GP. The longitudinal course of psychopathology in Cushing's syndrome after correction of hypercortisolism. J Clin Endocrinol Metab. 1997;82:3912-9.

6. Kaltsas GA, Giannulis MG, Newell-Price JD, Dacie JE, Thakkar $C$, Afshar $\mathrm{F}$ et al. A critical analysis of the value of simultaneous inferior petrosal sinus sampling in Cushing's disease and the occult ectopic adrenocorticotropin syndrome. J Clin Endocrinol Metab. 1999;84:487-92.

7. Machado MC, de Sa SV, Domenice S, Villares Fragoso MCB, Puglia P, Albergaria Pereira MA, et al. The role of desmopressin in bilateral and simultaneous inferior petrosal sinus sampling for differential diagnosis of CATH-dependent Cushing's syndrome. Clin Endocrinol (Oxf). 2007;66:136-42.

8. Tsagarakis S, Vassiliadi D, Kaskarelis IS, Komninos J, Souvatzoglou E, Thalassinos N. The Application of the Combined Corticotropin-Releasing Hormone plus Desmopressin Stimulation during Petrosal Sinus Sampling Is Both Sensitive and Specific in Differentiating Patients with Cushing's Disease from Patients with the Occult Ectopic Adrenocorticotropin Syndrome. J Clin Endocrinol Metab. 2007;92:2080-6.

9. Aron DC, Raff H, Findling JW. Effectiveness versus efficacy: the limited value in clinical practice of high dose dexamethasone suppression testing in the differential diagnosis of adrenocorticotropin-dependent Cushing's syndrome. J Clin Endocrinol Metab. 1997;82:1780-85.

10. Singer W, Kovacs K, Ryan N, Horvath E. Ectopic ACTH syndrome: clinicopathological correlations. J Clin Pathol. 1978;31:591-8.
11. Carey RM, Varma SK, Drake CR Jr, Thorner MO, Kovacs K, Rivier $\mathrm{J}$ et al. Ectopic secretion of corticotropin-releasing factor as a cause of Cushing's syndrome. A clinical, morphologic, and biochemical study. N Engl J Med. 1984;311:13-20.

12. Schteingart DE, Lloyd RV, Akil H, Chandler WF, Ibarra-Perez G, Rosen SG et al. Cushing's syndrome secondary to ectopic corticotropin-releasing hormone-adrenocorticotropin secretion. J Clin Endocrinol Metab. 1986;63:770-5.

13. Winquist EW, Laskey J, Crump M, Khamsi F, Shepherd FA. Ketoconazole in the management of paraneoplastic Cushing's syndrome secondary to ectopic adrenocorticotropin production. J Clin Oncol. 1995;13:157-64.

14. Kosmidis PA, Samantas E, Fountzilas G, Plavidis N, Apostolopoulou F, Skarlos D. Cisplatin/Etoposide versus Carboplatin/ Etoposide chemotherapy and irradiation in small cell lung cancer: a randomized phase III study. Semin Oncol. 1994;21:23-30.

15. Zeiger MA, Fraker DL, Pass HI, Nieman LK, Cutler Jr. GB, Chrousos GP, et al. Effective reversibility of the signs and symptoms of hypercortisolism by bilateral adrenalectomy. Surgery. 1993;114:1138-43.

16. Chow JT, Thompson GB, Grant CS, Farley DR, Richards ML, Young WF. Bilateral laparoscopic adrenalectomy for corticotrophin-dependent Cushing's syndrome: a review of the Mayo Clinic experience. Clin Endocrinol (Oxf). 2008;68:513-9.

\section{Corresponding to:}

David Araujo-Vilar

Servicio de Endocrinoloxía e Nutrición

Hospital Clínico Universitario de Santiago

Tv da Choupana s/n

15706 Santiago de Compostela, Spain

E-mail: david.araujo@usc.es 